\title{
Analisis Faktor-Faktor Yang Mempengaruhi Tingkat Kedisiplinan Kerja Pegawai Pada Kantor Satuan Polisi Pamong Praja Kota Pontianak
}

\author{
ADIYANTO \\ APRINA KUSWARDANI \\ STIE Boedi Oetomo \\ Jl. Ampera, No. GG 1-2 Kota Baru, Pontianak \\ email : aprinakuswardani23@gmail.com
}

Diterima 4 September 2018; disetujui 2 November 2018;

\begin{abstract}
: the human resource is a very important asset and a valuable productivity and efficiency should be improved to make it more powerful and able to optimally in achieving the desired results. Police units of teachers 'Praja Pontianak town in terms of the Organization's operational strategy adequate to carry out the tasks and authorities in accordance with the principles and activities of the organization. One of the indicators of the quality of work of employees in an organization or Government agency can be seen from the level of observance or discipline employees in your organization or agency. So discipline is the key to the success of a number of agencies in achieving its goals. The purpose of this research is to know the factors that affect the level of discipline of work employees on Police teachers 'Praja Pontianak town. The number of samples as many as 40 people. Determination of the number of samples specified with Stratified Random Sampling. This study used multiple Linear regression analysis technique. Simultaneously it can be concluded that the factor is goals and capabilities, exemplary leadership, retribution, justice, waskat, legal sanctions and humanitarian relations significantly influential/real against the level of discipline in the Police officer's work Teachers. Praja Pontianak Town. It can be concluded that a partially variable goals and capabilities, exemplary leadership, retribution, justice, waskat, legal and humanitarian relations sanctions take effect against the real level of discipline on Police officers working Teachers The Municipal City of Pontianak.
\end{abstract}

Keywords: Human resources, Work Discipline and Supervision

\section{PENDAHULUAN}

Proses pelaksanaan pembangunan dan pengabdian kepada bangsa dan negara ini tentu sumber daya manusia adalah suatu bagian yang sangat memegang peranan penting. Hal ini karena unsur manusialah yang menentukan dan memprediksikan keberhasilan atau kegagalan suatu kebijaksanaan, strategi maupun langkah-langkah kegiatan operasional suatu kegiatan. Pendek kata, apapun bentuk dan kegiatan suatu organisasi, manusia selalu memainkan peranan penting di dalamnya. Peningkatan dan pertumbuhan atau pertumbuhan suatu wadah atau organisasi dalam kehidupan masyarakat sangat erat kaitannya dengan keberadaan manusia yang ada di dalamnya sebagai penggerak atau motivator utama organisasi atau wadah tersebut. Karenanya sumber daya manusia adalah merupakan aset yang sangat penting dan berharga yang harus ditingkatkan produktivitas dan efisiensinya agar lebih berdaya guna dan dapat optimal dalam mencapai hasil yang diinginkan. 
Manusia yang disebut sebagai pegawai pada suatu instansi harus dilatih dan diarahkan agar dapat menjalankan kegiatan yang telah ditetapkan baik oleh instansi pemrintah maupun swasta. Selain melatih dan mengarahkan pegawa, setiap instansi juga harus peka terhadap kebutuhan dan keinginan pegawai selama bekerja. Jika kedua komponen tersebut tidak dijalankan maka dapat menimbulkan masalah yang mengakibatkan kerugian bagi suatu instansi. Kerugian yang diderita oleh suatu instansi mencakup kerugian biaya dan kerugian sumber daya manusia. Masalah yang sering dihadapi oleh suatu instansi diantaranya adalah masalah disiplin kerja yang rendah dalam diri pegawai tersebut.

Kedisiplinan diartikan bilamana pegawai selalu datang dan pulang tepat pada waktunya, mengerjakan semua pekerjaannya dengan baik, mematuhi semua peraturan suatu instansi dan normanorma sosial yang berlaku. Peraturan sangat diperlukan untuk memberikan bimbingan dan penyuluhan bagi pegawai dalam menciptakan tata kerja yang baik sehingga menimbulkan semangat kerja yang baik, efisiensi yang tinggi, moral kerja yang baik dan efektifitas kerja pegawai semakin meningkat.

Adapun tujuan dari penelitian ini adalah untuk mengetahui faktor-faktor yang mempengaruhi tingkat kedisiplinan kerja pegawai pada Satuan Polisi Pamong Praja Kota Pontianak.

\section{LANDASAN TEORI}

Manullang (1990), manajemen sumber daya manusia adalah seni dan ilmu pengadaan, pengembangan dan pemanfaatan sumber daya manusia, sehingga tujuan organisasi dilaksanakan secara daya guna dan adanya kegairahan kerja dari semua tenaga kerja.

Sinungan, M (2000) menyatakan bahwa ketaatan (obedience) sama dengan disiplin yang berarti kepatuhan terhadap ketentuan dan peraturan pemerintah atau etik, norma dan kaidah yang berlaku dalam masyarakat.

Sastrohadiwiryo, BS (2002) menyatakan bahwa disiplin kerja dapat didefinisikan sebagai suatu sikap menghormati, menghargai, patuh dan taat terhadap peraturan-peraturan yang berlaku baik yang tertulis maupun yang tidak tertulis serta sanggup menjalankannya dan tidak mengelak untuk menerima sanksi-sanksinya apabila ia melanggar tugas dan wewenang yang diberikan kepadanya.

Sondang P. Siagian (1989 : 135) pengawasan adalah proses pengamatan dari pelaksanan seluruh kegiatan organisasi untuk menjamin agar semua pekerjaan yang sedang dilakukan berjalan sesuai dengan rencana yang telah ditentukan sebelumnya.

Tujuan penelitian ini adalah mengetahui dan menganalisis faktor-faktor yang mempengaruhi tingkat kedisiplinan kerja pegawai pada kantor Satuan Polisi Pamong Praja Kota Pontianak

Penelitian Terdahulu. Wahyuningrum (2008) melakukan penelitian mengenai hubungan kemampuan, kepuasan dan disiplin kerja dengan kinerja pegawai di Kecamatan Tanggungharjo Kabupaten Grobogan. Hasil penelitiannya adalah bahwa disiplin kerja di Kecamatan Tanggungharjo Kabupaten Grobogan termasuk dalam kategori baik, hal lain yang dapat dicapai karena didukung oleh faktor-faktor antara lain: adanya kesadaran diri dari masing-masing pegawai itu sendirimaka setiap berangkat kekantor dan mulai mengerjakan pekerjaan sebagian besar pegawai selalu tepat waktu, namun ada juga pegawai yang datang kekantor yang tidak sesuai dengan peraturan.

Wahyudi (2006) melakukan penelitian tentang Pengaruh Pengendalian terhadap Kinerja Pegawai pada Biro Organisasi Sekretariat Daerah propinsi Jawa Barat. Hasil penelitian Wahyudi (2006) menunjukan bahwa kinerja pegawai di lingkungan Biro Organisasi Sekretariat Daerah propinsi Jawa Barat ternyata tidak hanya dipengaruhi oleh variabel pengendalian semata tetapi ada faktor atau variabel lain yang ikut mempengaruhi terhadap kinerja pegawai tersebut sebesar $13 \%$.

Hipotesis. Terdapat Faktor-Faktor Yang Mempengaruhi Tingkat Kedisiplinan Kerja Pegawai Pada Kantor Satuan Polisi Pamong Praja Kota Pontianak.

\section{METODE PENELITIAN}

Metode yang dipakai dalam penelitian ini adalah metode penelitian deskriptif dengan metode survey yaitu mengambil objek penelitian pada pegawai pada Satuan Polisi Pamong Praja Kota Pontianak. Populasi dalam penelitian ini adalah 


\section{Gambar 1 \\ Kerangka Penelitian Analisis Faktor-Faktor Yang Mempengaruhi Tingkat Kedisiplinan Kerja Pegawai Pada Kantor Satuan Polisi Pamong Praja Kota Pontianak}

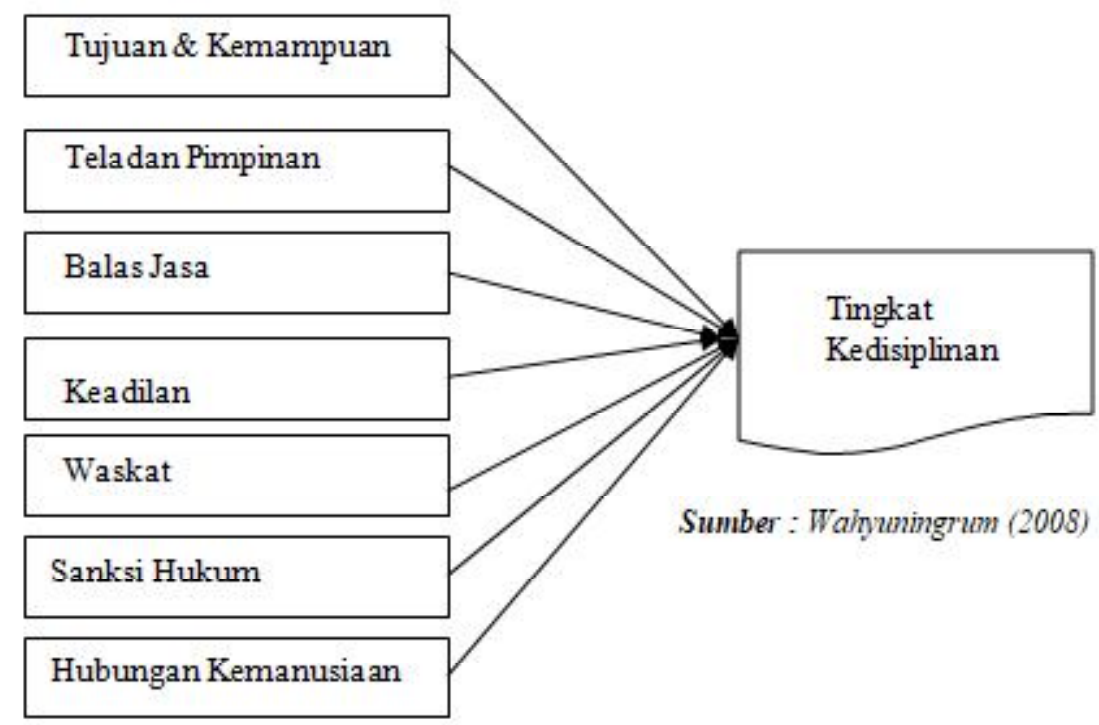

Tabel 1

Definisi Operasional Variabel

\begin{tabular}{|c|c|c|}
\hline Variabel & Sub Variabel & Pengukuran \\
\hline $\begin{array}{l}\text { Variabel Terikat : Kedisiplinan (Y) } \\
\text { Sastrohadiwiryo, BS (2002) menyatakan bahwa disiplin kerja dapat didefinisikan } \\
\text { sebagai suatu sikap menghormati, menghargai, patuh dan taat terhadap peraturan- } \\
\text { peraturan yang berlaku baik yang tertulis maupun yang tidak tertulis serta sanggup } \\
\text { menjalankannya dan tidak mengelak untuk menerima sanksi-sanksinya apabila ia } \\
\text { melanggar tugas dan wewenang yang diberikan kepadanya. }\end{array}$ & $\begin{array}{l}\text { Untuk variabel ki- } \\
\text { nerja meliputi kete- } \\
\text { patan waktu, keta- } \\
\text { atan terhadap per- } \\
\text { aturan dan tang- } \\
\text { gung jawab kerja. }\end{array}$ & Skala Likert \\
\hline
\end{tabular}

\section{Variabel Bebas :}

1.Tujuan \& Kemampuan (X1)Malayu S.P Hasibuan (1997), tujuan dan kemampuan Tujuan dalam be- Skala Likert ikut mempengaruhi tingkat kedisiplinan karyawan. Tujuan yang akan dicapai harus kerja, kesesuaian jelas dan ditetapkan secara ideal serta cukup menantang bagi kemampuan karyawan. tingkat pendidikan 2. Teladan pimpinan (X2)Malayu S.P Hasibuan (1997), teladan pimpinan sangat Panutan pimpi-nan, Skala Likert berperan dalam menentukan kedisiplinan karyawan karena pimpinan dijadikan sikap seorang pimteladan dan panutan oleh para bawahan. Pimpinan harus memberikan contoh yang pinan baik, berdisiplin baik, jujur, adil dan sesuai kata dengan perbuatan.

3. Balas jasaMalayu S.P Hasibuan (1997), balas jasa ikut mempengaruhi kedisiplinan Gaji dan Skala Likert karyawan karena balas jasa akan memberikan kepuasan dan kecintaan karyawan penghargaan terhadap perusahaan ataupun terhadap pekerjanya. Jika kecintaan itu semakin baik

maka kedisiplinan mereka akan baik.

4. KeadilanMalayu S.P Hasibuan (1997), keadilan ikut mendorong terwujudnya Perlakuan atasan Skala Likert kedisiplinan karyawan karena ego dan sifat manusia yang selalu merasa dirinya terhadap Pegawai penting dan minta diperlakukan sama dengan manusia lainnya.

5.WaskatMalayu S.P Hasibuan (1997), pengawasan melekat adalah tindakan nyata Arahan pimpinan Skala Likert dan paling efektif dalam mewujudkan kedisiplinan karyawan perusahaan karena dengan waskat ini berarti atasan harus efektif dan langsung mengawasi perilaku, moral, sikap, gairah kerja dan prestasi kerja.

6. Sanksi hukumanMalayu S.P Hasibuan (1997), sanksi hukuman berperan penting Penerapan sanksi Skala Likert dalam memelihara kedisiplinan karyawan karena dengan sanksi hukuman yang semakin berat maka karyawan semakin takut untuk melanggar peraturan-peraturan perusahaan, sikap dan perilaku yang indisipliner.

7. Hubungan KemanusiaanMalayu S.P Hasibuan (1997), hubungan kemanusiaan Hubungan vertikal Skala Likert yang harmonis diantara sesama karyawan ikut menciptakan kedisiplinan yang baik dan horisontal pada suatu perusahaan. Hubungan itu bersifat vertikal maupun horizontal yang terdiri hubungan karyawan dengan atasan dan hubungan sesama karyawan. 
seluruh pegawai negeri sipil pada Satuan Polisi Pamong Praja Kota Pontianak sebanyak 110 orang dan sampel pada penelitian ini adalah 40 orang pegawai Satuan Polisi Pamong Praja Kota Pontianak. Variabel bebas terdiri dari 7 yaitu tujuan dan kemampuan, teladan pimpinan, balas jasa, keadilan, waskat, sanksi hukum dan hubungan kemanusian, sedangkan variabel terikat yaitu kedisiplinan, untuk mendapatkan data di penelitian ini dengan cara kuesioner.

Teknik analisis data menggunakan analisis kualitatif dengan mentabulasikan jawaban responden ke bentuk tabel, kemudian dipersentasekan serta adanya suatu analisis terhadap karakteristik responden dan faktor-faktor yang mempengaruhi tingkat kedisiplinan kerja pegawai pada Satuan Polisi Pamong Praja Kota Pontianak.

\section{HASIL PENELITIAN}

\section{Pernyataan Responden terhadap Faktor- Faktor yang Mempengaruhi Disiplin Kerja Pegawai Satuan Polisi Pamong Praja Kota Pontianak}

\section{Tujuan dan Kemampuan}

Dari 40 orang responden yang di jadikan sampel penelitian ini berdasarkan tujuan, diketahui bahwa sebanyak 11 orang responden atau sebesar $27,50 \%$ mengatakan bahwa tujuan mereka bekerja untuk mencari nafkah guna memenuhi kebutuhan sehari-hari, sebanyak 26 orang responden atau sebesar 65,00\% mengatakan untuk mencari status pekerjaan dan sebanyak 3 orang responden atau sebesar 7,50\% mengatakan untuk mengembangkan skill. Dari 40 orang responden yang di jadikan sampel penelitian ini berdasarkan kemampuan diketahui bahwa sebanyak 14 orang responden atau sebesar 35,00\% mengatakan bahwa antara pendidikan dengan bidang kerja yang dilaksanakan sangat sesuai. Sebanyak 22 responden atau $55,00 \%$ mengatakan bahwa antara pendidikan dengan bidang kerja yang dilaksanakan sesuai dengan tingkat pendidikannya, dan sebanyak 4 orang responden atau $10.00 \%$ mengatakan bahwa antara pendidikan dengan bidang kerja yang dilaksanakan cukup sesuai dengan tingkat pendidikannya.

\section{Keteladanan Pemimpin}

Dari 40 orang responden yang di jadikan sampel penelitian ini berdasarkan keteladanan pemimpin, diketahui bahwa sebanyak 19 orang responden atau sebesar $47,50 \%$ mengatakan bahwa atasan sangat dapat menjadi panutan dihadapan pegawai. Sebanyak 15 orang responden atau sebesar 37,50\% mengatakan bahwa atasan dapat menjadi panutan dihadapan pegawai, dan sebesar 15,00\% atau sebanyak 6 orang yang mengatkan bahwa atasan tidak dapat menjadi panutan.

\section{Balas Jasa}

Dari 40 orang responden yang di jadikan sampel penelitian ini berdasarkan balas jasa, diketahui bahwa sebanyak 15 orang responden atau $37.50 \%$ menerima gaji setiap bulanya sebesar diatas Rp. 3.000.000,00. Sebanyak 24 orang responden atau $60.00 \%$ menerima gaji setiap bulannya sebesar Rp. 2.000.000,00 - Rp. 3.000.000,00 bulan. Gaji yang diterima oleh responden adalah didasarkan pada pangkat dan golongan serta jabatan yang melekat pada responden itu sendiri.

\section{Keadilan}

Dari 40 orang responden yang di jadikan sampel penelitian ini berdasarkan keadilan diketahui, bahwa sebanyak 20 orang responden atau sebesar 50,00\%, mengatakan bahwa atasan memperlakukan pegawai secara sangat adil. Sebanyak 10 orang responden atau sebesar $25,00 \%$, mengatakan bahwa atasan memperlakukan pegawai secara adil. Sebanyak 10 orang responden atau sebesar $25,00 \%$, mengatakan bahwa atasan memperlakukan pegawai secara tidak adil.

\section{Waskat}

Dari 40 orang responden yang di jadikan sampel penelitian ini berdasarkan waskat, diketahui bahwa sebanyak 17 orang responden atau $42,50 \%$, mengatakan bahwa atasan sering memberikan pengarahan bagi pegawai, sebanyak 18 orang responden atau $45,00 \%$, mengatakan bahwa atasan jarang memberikan pengarahan bagi pegawai, dan sebanyak 5 orang responden atau $12,50 \%$, mengatakan bahwa atasan tidak pernah memberikan pengarahan bagi pegawai. 


\section{Sanksi}

Dari 40 orang responden yang di jadikan sampel penelitian iniberdasarkan sanksi yang ada, diketahui bahwa seluruh responden atau 40 orang atau sebesar $100,00 \%$ mengatakan bahwa ada sanksi yang diberikan atasan jika melakukan pelanggaran terhadap peraturan kedinasan. Dari 40 orang responden yang di jadikan sampel penelitian ini berdasarkan sanksi yang di berikan bagi pelanggar, diketahui bahwa sebanyak 17 orang responden atau $42,50 \%$, mengatakan bahwa sanksi yang diberikan sangat sesuai dengan kesalahan. Sebanyak 23 orang responden atau 57,50\%, mengatakan bahwa sanksi yang diberikan sesuai dengan kesalahan.

\section{Hubungan Kemanusian}

Dari 40 orang responden yang di jadikan sampel penelitian ini berdasarkan hubungan kemanusiaan (sesama pegawai), diketahui bahwa sebanyak 9 orang responden atau $22,50 \%$, mengatakan bahwa hubungan kerja mereka dengan sesama pegawai sangat baik. Sebanyak 31 orang responden atau $77,50 \%$, mengatakan bahwa hubungan kerja mereka dengan sesama pegawai lain tergolong baik. Dari 40 orang responden yang di jadikan sampel penelitian ini berdasarkan hubungan kemanusiaan ( dengan atasan), diketahui bahwa sebanyak 19 orang responden atau $47,50 \%$, mengatakan bahwa hubungan pegawai dengan atasan sangat baik. Sebanyak 21 orang responden atau $52,50 \%$, mengatakan bahwa hubungan pegawai dengan atasan tergolong baik.

Dari hasil analisis pada tabel 1 diketahui bahwa nilai uji secara simultan atau nilai $F$ hitung sebesar 19.259 pada tingkat signifikan 0.000 dan karena tingkat probabilitasnya 0.000 jauh lebih kecil dari 0.05 maka model regresi ini dapat digunakan untuk memprediksi hubungan antara variabel independent terhadap variabel dependent. Dari hasil analisis tabel 1 juga diperoleh besarnya koefisien Determinasi $\left(\mathrm{R}^{2}\right)$ sebesar $80,8 \%$, sehingga dapat disimpulkan bahwa variabel indpendent tujuan dan kemampuan, keteladanan pimpinan, balas jasa, keadilan, Waskat, sanksi hukum dan hubungan kemanusiaan mempengaruhi naik turunnya (variasi) terhadap tingkat kedisiplinan kerja sebesar $80,8 \%$, sedangkan sisanya sebesar $19,2 \%$ dijelaskan oleh variabel lain diluar variabel pengamatan. Nilai $\mathrm{F}$ tabel 0.05 adalah sebesar 2,31, sedangkan nilai $\mathrm{F}$ hitung sebesar 19,259. Jadi nilai F hitung > nilai F tabel, sehingga dapat disimpulkan bahwa variabel pengamatan (variable independent) berpengaruh yang nyata (signifikan) terhadap tingkat kedisiplinan kerja pegawai pada Satuan Polisi Pamong Praja Kota Pontianak.

Dari hasil uji parsial pada tabel 2 diatas, Secara parsial variabel tujuan dan kemampuan memiliki nilai t hitung sebesar 2,504 dimana lebih besar dari $\mathrm{t}$ tabel $\alpha 0.05$, yaitu 2,675>1,697, secara parsial variabel keteladanan pimpinan memiliki nilai t hitung sebesar 2,264 dimana lebih besar dari t tabel $\alpha 0.05$, yaitu $2,264>1,697$, secara parsial variabel balas jasa memiliki nilai t hitung sebesar 5,206 dimana lebih besar dari t tabel $\alpha 0.05$, yaitu 5,206 $>1,697$, secara parsial variabel keadilan memiliki nilai t hitung sebesar 5,900 dimana lebih besar dari $\mathrm{t}$ tabel $\alpha 0.05$, yaitu 5,900>1,697, secara parsial variabel waskat memiliki nilai t hitung sebesar 1,965 dimana lebih besar dari t tabel $\alpha 0.05$, yaitu 1,965 $>1,697$, secara parsial variabel sanksi hukum memiliki nilait hitung sebesar 1,837 dimana lebih besar darit tabel $\alpha 0.05$, yaitu $1,837>1,697$ dan secara parsial variabel hubungan kemanusian memiliki nilait hitung sebesar 2,197 dimana lebih besar dari t tabel $\alpha 0.05$, yaitu $2,197>1,697$.

Tabel 2

Analisis Of Variance Variabel Penelitian Terhadap Tingkat Kedisiplinan Kerja

\begin{tabular}{llllll}
\hline \multicolumn{1}{c}{ Model } & df & $\begin{array}{l}\text { Sum Of } \\
\text { Square }\end{array}$ & $\begin{array}{l}\text { Mean } \\
\text { Square }\end{array}$ & F & Sig. \\
\hline Regression & 7 & 4,122 & 0,589 & 19,259 & $.000^{\text {a }}$ \\
Residual & 32 & 0,978 & 0,031 & & \\
\hline Total & 39 & 5,100 & & & \\
\hline
\end{tabular}

Sumber : Hasil Analisis Data, 2017 


\section{PEMBAHASAN}

Berdasarkan jawaban dari 40 responden diketahui variabel tujuan dan kemampuan secara simultan Nilai F tabel 0.05 adalah sebesar 2,31, sedangkan nilaiF hitung sebesar 19,259. Jadi nilai F hitung $>$ nilai $F$ tabel, sehingga dapat disimpulkan bahwa variabel pengamatan (variable independent) berpengaruh yang nyata (signifikan) terhadap tingkat kedisiplinan kerja pegawai pada Satuan Polisi Pamong Praja Kota Pontianak. Kesimpulan pada penelitian ini sesuai dengan pendapat Fink (1992), yaitu bahwa komitmen terhadap organisasi dalam artian ketaatan dan disiplin mempunyai 3 dimensi yaitu identifikasi dengan kerja, identifikasi dengan rekan kerja, dan identifikasi dengan organisasional. Tiga dimensi ini mempunyai hubungan dengan praktek manajemen, sistem imbalan, dan kinerja karyawan. Selain itu pula kenyataan ini didukung oleh keadaan bahwa para responden yang menyatakan bahwa pada kondisi organisasi yang ada cukup menunjang terciptanya loyalitas karyawan terhadap organisasi yang tentunya ditunjang oleh imbalan yang memadai dan praktek manajemen yang lebih proporsional.

Secara parsial yang mempunyai pengaruh yang nyata terhadap tingkat kedisiplinan kerja pegawai pada Satuan Polisi Pamong Praja Kota Pontianak, variabel teladan pimpinan secara parsial yang mempunyai pengaruh yang nyata terhadap tingkat kedisiplinan kerja pegawai pada Satuan Polisi
Pamong Praja Kota Pontianak, variabel balas jasa secara parsial yang mempunyai pengaruh yang nyata terhadap tingkat kedisiplinan kerja pegawai pada Satuan Polisi Pamong Praja Kota Pontianak, variabel keadilan secara parsial yang mempunyai pengaruh yang nyata terhadap tingkat kedisiplinan kerja pegawai pada Satuan Polisi Pamong Praja Kota Pontianak, variabel waskat secara parsial yang mempunyai pengaruh yang nyata terhadap tingkat kedisiplinan kerja pegawai pada Satuan Polisi Pamong Praja Kota Pontianak, variabel sanksi hukum secara parsial yang mempunyai pengaruh yang nyata terhadap tingkat kedisiplinan kerja pegawai pada Satuan Polisi Pamong Praja Kota Pontianak, variabel hubungan kemanusian secara parsial yang mempunyai pengaruh yang nyata terhadap tingkat kedisiplinan kerja pegawai pada Satuan Polisi Pamong Praja Kota Pontianak.

\section{SIMPULAN}

Kesimpulan. Berdasarkan hasil analisis mengenai faktor-faktor yang mempengaruhi tingkat kedisiplinan kerja pegawai pada Satuan Polisi Pamong Praja Kota Pontianak, maka terdapat beberapa hal yang dapat disimpulkan dari hasil penelian ini, yaitu :

1. Besarnya koefisien Determinasi $\left(\mathrm{R}^{2}\right)$ sebesar $80,8 \%$, sehingga dapat disimpulkan bahwa variabel indpendent mempengaruhi naik turunnya (variasi) terhadap tingkat kedisiplinan

Tabel 3

Analisis Fungsi Regresi dan Uji Secara Parsial Antara Variabel Independent terhadap Tingkat Kedisiplinan Kerja

\begin{tabular}{lccccc}
\hline \multirow{2}{*}{ Model } & \multicolumn{2}{c}{$\begin{array}{c}\text { Unstandardized } \\
\text { Coefficients }\end{array}$} & $\begin{array}{c}\text { Standardized } \\
\text { Coefficients }\end{array}$ & $\mathrm{t}$ & Sig. \\
\cline { 2 - 4 } & $\mathrm{B}$ & Std. Error & Beta & & \\
\hline (Constant) & 0,209 & 0,430 & & 0,487 & 0,556 \\
TK & 0,146 & 0,055 & 0,228 & 2,675 & 0,018 \\
TP & 0,096 & 0,042 & 0,194 & 2,264 & 0,069 \\
BK & 0,270 & 0,052 & 0,531 & 5,206 & 0,000 \\
KN & 0,215 & 0,037 & 0,500 & 5,900 & 0,000 \\
WK & 0,107 & 0,054 & 0,203 & 1,965 & 0,098 \\
SH & 0,123 & 0,067 & 0,163 & 1,837 & 0,047 \\
HK & 0,172 & 0,078 & 0,229 & 2,197 & 0,040 \\
\hline
\end{tabular}

Dependent Variable: Tingkat Kedisiplinan Kerja

Sumber : Hasil Analisis Data, 2017 
kerja sebesar $80.8 \%$, sedangkan sisanya sebesar 19,2\% dijelaskan oleh variabel lain diluar variabel pengamatan.

2. Nilai $F$ hitung $>$ nilai $F$ tabel, sehingga dapat disimpulkan bahwa variable independent berpengaruh yang nyata terhadap tingkat kedisiplinan kerja pegawai pada Satuan Polisi Pamong Praja Kota Pontianak.

3. Variabel independent tujuan dan kemampuan, teladan pimpinan, balas jasa, keadilan, waskat, sanksi hukum dan hubungan kemanusiaan mempengaruhi naik turunnya (variasi) terhadap tingkat kedisiplinan kerja pegawai pada Satuan Polisi Pamong Praja Kota Pontianak.

\section{Saran}

1. Dalam melakukan pengawasan, hendaknya atasan lebih sering memberikan pengarahan kepada para pegawai.

2. Untuk menciptakan kedisiplinan pegawai, maka perlu memberikan penilaian atas prestasi kerja sesuai hasil yang dicapai dengan jaminan kompensasi yang jelas, meningkatkan ketaatan jam kerja pegawai, memberikan promosi (jenjang karir) yang tepat bagi pegawai yang disiplin dan berpresatasi serta menjatuhkan sanksi atau hukuman (punishment) kepada pegawai yang terbukti melanggar disiplin kerja.

3. Bagi pegawai yang dapat menjalankan disiplin kerja dengan baik seharusnya dapat diberikan insentif tambahan (reward) yang layak.

4. Perlu dilakukan sosialisasi dan konsistensi mengenai penerapan peraturan kepegawaian untuk meningkatkan disiplin pegawai.

\section{DAFTAR PUSTAKA}

As'ad Moh. 1993. Psikologi Industri, Edisi Keenam, Penerbit Liberty, Yogyakarta.

Dharma, Agus. 1992. Manajemen Prestasi Kerja. Penerbit CV. Rajali Press. Jakarta.

Handoko, T. 1998. Manajemen Personalia Dan Sumber Daya Manusia. BPFE, Yogyakarta.
Hasibuan, Malayu S.P. Drs., 1997. Manajemen Pengertian dan Masalah, Jakarta, Kanisius.

Kartono, 1994. Pengantar Metodologi Riset. Penerbit CV. Mandar Maju. Bandung.

Moenir, AS. 1987. Pendekatan Manusiawi dan Organisasi Terhadap Pembinaan Kepegawaian. Jakarta. Penerbit PT. Gunung Agung.

Manullang M. 1990. Manajemen Personalia, Penerbit Ghalia Indonesia, Jakarta.

Peraturan Pemerintah (PP) Republik Indonesia Nomor 10 Tahun 1979 tentang Penilaian Pelaksanaan Pekerjaan Pegawai Negeri Sipil.

Peraturan Pemerintah (PP) Republik Indonesia Nomor 10 Tahun 1979 tentang Penilaian Pelaksanaan Pekerjaan Pegawai Negeri Sipil dalam penjelasan pasal 4 ayat (2) huruf d.

Peraturan Pemerintah Nomor 30 Tahun 1980 tentang Peraturan Disiplin Pegawai Negeri Sipil, dalam pasal 2.

Reksohadiprojo, Handoko.1990. Dasar-dasar Manajemen, Edisi ke 5 BPFE, Yogyakarta.

Rao, TV. 1991. Prestasi Penilaian Kerja Teori dan Praktek. Terjemahan Ny. L.

Mulyana, Seri Manajemen No.9, PT. Pustaka Binaman, Pressindo, Jakarta.

Soedjono, Imam, 1983, Disiplin Pegawai Negeri. Jakarta. Penerbit PT. Intan Pariwara.

Sarwoto.1989. Dasar-Dasar Organisasi Dan Manajemen, Penerbit Ghalia Indonesia, Jakarta.

Siagian, SP. 1989. Manajemen Sumber Daya Manusia. Bumi Aksara Jakarta.

Suwarno, Hadayaningrat, 1990. Pengantar Umum Pendidikan. Penerbit Rineka Cipta. Jakarta.

Suryosubroto. 1990. Beberapa Aspek Dasar Kependidikan. Penerbit Rineka Cipta. Jakarta.

Singarimbun, Masri dan Sofian Effendi, 1993. Metode Penelitian Survei, Jakarta LP3ES.

Sudjana. 1993. Statistika Untuk Ekonomi Dan Niaga II. Tarsito. Bandung.

Saydam, G, 2000. Manajemen Sumber Daya Manusia. Penerbit PT. Toko Gunung Agung, Jakarta.

Sinungan, M. 2000. Produktivitas Apa Dan Bagaimana . Penerbit Bina Asara. Jakarta.

Wursanto. Ing, 1989, Manajemen Kepegawaian, Jilid II. Jakarta. Penerbit Kanisius Jakarta.

Warisa, 1991. Demografi Dan Produktivitas. CV. Yasaguna. Bandung. 